\title{
Ideation in Industrial Design Context: The importance of group process in brainstorming
}

\author{
Amer Shakir Zainol' ${ }^{1}$, Wan Zaiyana Mohd Yusof², \\ Khairul Anwar Mastor ${ }^{3}$, Zuraidah Mohd Sanusi ${ }^{4}$ \\ 1Faculty of Art \& Design, \\ 2Director, National Design Centre, \\ 4Postgraduate Research, Faculty of Accountancy, \\ Universiti Teknologi MARA, Shah Alam, Malaysia \\ ${ }^{3}$ Director, Centre for General Studies., \\ Universiti Kebangsaan Malaysia, Bangi, Malaysia \\ amers78f@salam.uitm.edy.my
}

\begin{abstract}
Brainstorming is a series of procedures (rules) designed to maximize the productivity of groups engaged in idea generation by reducing production loss, popularized by Osborn, an advertising executive. The main concern in this tool is increasing creativity in an organization. This study examines two main factors, production loss and ownership of the topic that influence the performance in group brainstorming. Production loss includes activities in production blocking, social loafing and evaluation apprehension among individuals, while ownership of the topic relates to the interest of individuals in engaging the brainstorming activities especially in industrial design. Using a quasi-experimental research design, this study reports on the participation of 115 groups of university students from 6 different universities. The data is analyzed at group-level. The hypotheses of this study are tested using Partial Least Squares (PLS) regression. Results reveal that out of the three dimensions of production loss, production blocking, social loafing, and evaluation apprehension, production blocking is negatively related to the group brainstorming performance whereas evaluation apprehension is positively related to the performance or group brainstorming. As expected, ownership or the topic is related to the performance too. However, social loafing is not related to the performance or group brainstorming. The results are of potential interest to educators, and researchers. This study responds 10 a call for further brainstorming research.
\end{abstract}

Keywords: Industrial Design, Brainstorming, Production loss, Ownership of the Topic, Group-level Analysis.

eISSN 2514-751X @ 2016 The Authors. Published for AMER ABRA by e-International Publishing House, Ltd., UK.. This is an open access article under the CC BY-NC-ND license (http://creativecommons.org/licenses/by-nc-nd/4.0/). Peerreview under responsibility of AMER (Association of Malaysian Environment-Behaviour Researchers), ABRA (Association of Behavioural Researchers on Asians) and cE-Bs (Centre for Environment-Behaviour Studies), Faculty of Architecture, Planning \& Surveying, UniversitiTeknologi MARA, Malaysia.

https://doi.org/10.21834/aje-bs.v1i1.165 


\section{0 Introduction}

Industrial design is an area that contributes services such as creating and developing concepts and specifications for both users and manufacturers (The Industrial Design Society of America, 2(04). The term Industrial design that is always used interchangeably with product design and involves both engineering and aesthetic design (Ekberg, 2(05); however, it emphasizes users' consideration (Roozenburg \& Eekels, 1995). Therefore, Industrial Designers are not people who handle things related directly to engineering. Instead, they are concerned with the delivery of ideas to engineers (Hannah, 20(4). For instance, Alexander Graham Bell was the person responsible for the invention of the telephone, but Henry Dreyfuss was the Industrial designer responsible for giving the modern form to the phone (Hannah, 20(4). Hence, in an industrial design context, creativity is needed and plays an important role in helping to come up with ideas and solutions (Takala, Keinonen, \& Mantere, 2(06). In the Malaysian industrial design context, Rahman (2005) has revealed that Malaysian designers are preferred because they work well in dynamic teams, contributing to brainstorming practices by sharing explicit knowledge in organizations.

In an organizational setting, the essential of group creativity cannot be denied (Paulus, Larey, Putman, Leggett, \& Roland, 1996; Paulus, 2(00) because organizations use it to overcome the problem of inventing a new product (Paulus \& Brown, 2(07). This group creativity can be enhanced through brainstorming. For instance, in IDEO, Kelly (2001) has emphasized that creativity in design firms is not coincidental or mysterious, but can certainly be gained. Moreover, brainstorming is one of the most well-known tools for creative thinking (Isaksen, 1998). Therefore, small groups always contribute to good results for many practitioners in the field of Creative Problem Solving (Dorval, 1999) and imaginative tasks (Nickerson, 2003).

Malaysian designers are known to contribute well in dynamic teams through brainstorming practice (Rahman, 2(05). He contends that management practices such as metaphor and analogy application, brainstorming with experts and design managers are highly preferred as it all contributes to explicit knowledge (Rahman, 2005 p. 31). Moreover, brainstorming is a technique that emphasizes thinking activities. Nevertheless, most literature on this topic fails to adequately consider brainstorming in the industrial design context. Even though Rahman 2005) has stressed the importance of the brainstorming technique to gain new ideas, there is no empirical evidence to support Rahman's (2005) finding that brainstorming actually takes place within the context of industrial design education in Malaysia. Moreover, there is lack of group-level analysis of personality and group performance (Bolin \& Neuman, 2(06) which leads to accurate findings. Therefore, the objective of this study is to examine the influence of process on group brainstorming performance at the group level among industrial design students. 


\subsection{Literature Review And Hypotheses Development}

\subsection{Group Brainstorming}

Brainstorming is a series of procedures (rules) designed to maximize the productivity of groups engaged in idea generation by reducing production loss, popularized by Osborn, an advertising executive. The main concern of the development of this tool is to increase creativity in organization (Osborn, 1963). Brainstorming is also identified as a technique involving a variety of tools for generating ideas (Isaksen, 1998) and many people could produce many ideas compared to working alone (Osborn, 1963). The study on brainstorming began when Taylor, Berry, and Block (1958) examined through an empirical study, the effectiveness of brainstorming as claimed by Osborn in his influential book, Applied Imagination (1957). Since the study by Taylor et al. (1958), numerous other studies have been conducted such as by Bouchard and Hare (1970), Diehl and Stroebe (1987), Barki and Pinsonneault (200 I), Nijstad, van Vianen, Stroebe, and Lodewijkx, (2004) and Nijstad, Stroebe, and Lodewijkx (2006). Most of the studies on group brainstorming have emphasized group process.

\subsection{Group Process}

In brainstorming, group process plays an important role in group performance through the interaction of individuals in the group which introduces factors into the brainstorming process that acts to improve performance. In other words, it is called process gains (Dennis \& William, 2003). Meanwhile, the factors that act to impair performance are called production loss (Dennis \& William, 2003). In production loss, production blocking is defined as competition for speaking time in interactive groups (Diehl \& Stroebe, 1987), while Barki and Pinsonneault (200 I) define evaluation apprehension as individuals in groups who fear that their creative ideas would be evaluated and rejected by the group. Social loafing is defined as a decrease in effort when individuals perform in a group (Latane', William, \& Harkins, 1979).

Idea generation is an important determinant of the group brainstorming performance (Paulus, 2000; Paulus, Dzindolet, Poletes, and Camacho, 1993; Dennis, and Valacich, 1993). Therefore, Osborn (1963) and the other practitioners such as Rawlinson (1981) emphasize idea generation. Although there are several processes involved, most brainstorming researchers such as Diehl and Stroebe (1987) Shepherd, Briggs, Reinig, Yen, and Nunamaker Jr. (1996), Bolin and Neuman (2006), and Coskun (2005) agree that the three most prominent factors that always affect the brainstorming performance are Production Blocking, Social Loafing, and Evaluation Apprehension. Moreover, production blocking represents the cognitive process, social loafing represents the motivational factor, and evaluation represents the social psychological factor (Mullen, Johnson, \& Salas, 1991).

\subsection{Production Blocking}

Production blocking can be defined as a competition for speaking time in interactive groups (Diehl $\&$ Stroebe, 1987). Furnham and Yazdanpanahi (1995) define production blocking as a state 
where there is only one person who can speak at a time, while other group members wait for their turn. They also add that the waiting time would cause a loss of productivity in a brainstorming group. Production blocking occurs when individuals in the group cannot express their ideas because another group member is talking at the same time (Gallupe, Dennis, Cooper, Valacich, Bastianutti, \& Nunamaker Jr., 1992); subsequently, this would reduce the effectiveness of the brainstorming sessions (Gallupe, Bastianutti, \& Cooper, 1991).

\subsection{Social Loafing}

Social loafing is defined as a decrease in effort when individuals perform in group (Latane", William, \& Harkins, 1979) and it occurs only when their ideas are not identified or attended to by other group members (Paulus \& Brown, 2(07). According to Karau and Williams (1993), social loafing occurs when individuals tend to put in less effort when working in groups than when they are working individually. The term social loafing is the same as free-riding where individuals in a group do not put in adequate effort to produce creative ideas (Barki \& Pinsonneault, $200 \mathrm{l}$ )

\subsection{Evaluation Apprehension}

Diehl and Stroebe (1987) define evaluation apprehension as individuals who fear a negative reaction from group members and therefore withhold their ideas in brainstorming. Barki and Pinsonneault (2()()!) define evaluation apprehension as occurring when individuals in a group fear that their creative ideas would be evaluated and even rejected by the group. According to Gallupe et al. (1992), evaluation apprehension occurs when individuals in group withhold their ideas and feel that their ideas would not be approved by other members in the group. Therefore, the researcher's prediction regarding the process of brainstorming include:

H 1: There are relationships between group process (Production blocking, Social loafing, and evaluation apprehension) and the quantity of ideas put forward by industrial design students during brainstorming sessions

The exploratory sub-hypotheses are as follows:

$\mathrm{H}$ 1a: There is a relationship between Production blocking and the quantity of ideas shared by industrial design students.

$\mathrm{H} 1 \mathrm{~b}$ : There is a relationship between Social loafing and the quantity of ideas shared by industrial design students.

$\mathrm{H}$ 1c: There is a relationship between Evaluation apprehension and the quantity of ideas shared by industrial design students.

\subsection{Ownership of the Topic}

There are certain external factors that influence group brainstorming performance. One of the factors is ownership of the topic. The topic that is given in brainstorming is quite general to the subjects of a study (Dennis \& Valacich, 1993; Gallupe, Bastianuui, \& Cooper, 1991; Bolin \& 
Neuman, 2006; Paulus et al., 1993; Shepherd et al., 1996; Coskun, 2005; Nijstad et al., 2004). In relation to this point, the issue of unsuitable topics given in the study of brainstorming especially in the Industrial Design context has been raised by Zainol \& Yusof (2008). They suggest that the topic should interest the participants in the brainstorming session so that they can contribute creative ideas.

As suggested by Isaksen (1998), researchers in brainstorming should pay attention to the topic given to the participants. The right topic would allow participants to be more responsive to the kind of tasks, problems and challenges given to them as they would experience a sense of ownership of the topic. The researcher also suggests that future research should focus more on ownership because in brainstorming session, the task or topic given is more of an open ended or creative task. Therefore, the ownership of the topic in brainstorming should match the team members' field of interest. This view is supported by Barki and Pinsonneault (2001) and Nijstad et al. (2006) who demonstrated that unsuitable topics reduces the quality of ideas put forward by members of a team. Understanding the degree of ownership of the topic in a brainstorming study may help in determining the accuracy of this issue. The following hypothesis is proposed:

H2: There is a relationship between ownership of the topic and the quantity of ideas shared by industrial design students in brainstorming sessions.

\subsection{Conceptual Framework}

Based on the discussion above, we propose the following conceptual framework, as shown in Figure I. First, there is a direct relationship between production loss and quantity of ideas. Second, there is also a direct relationship between ownership of the topic and the quantity of ideas.

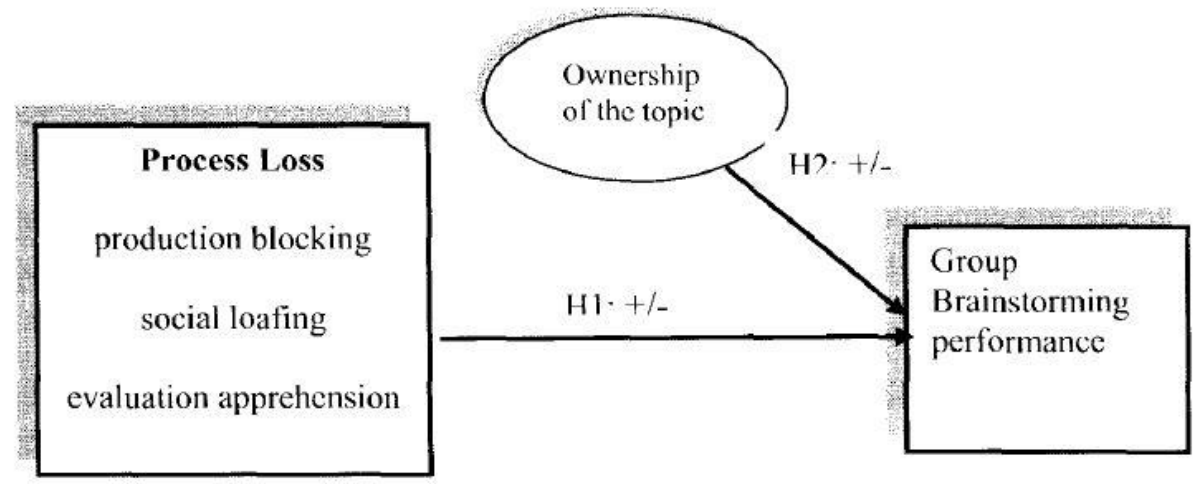

Figure 1: Conceptual Framework of Group Brainstorming Performance 


\subsection{Methodology}

\subsection{Research Design}

The researchers visited every university selected as venues for the brainstorming sessions. Firstly, the participants were gathered in a hall and were given a briefing and instructions for activities. There were 460 industrial design students pursuing degree-level courses in six universities in Malaysia. The participants were divided into small groups. Four-person groups were formed by using a simple random technique. The number of groups formed was 115 . The participants were reminded to place emphasis on the quantity of ideas shared, accept all ideas without criticism, encourage the sharing of novel ideas, and encouraged attempts at combining and improving ideas. To get the participants familiar with brainstorming sessions, warm-up topics were given and discussed for 5 minutes. This is supported by Osborn (1963) who recommended that people who had no knowledge about brainstorming should be exposed to an orientation to this technique. After the practice session, the actual topic on Malaysian furniture was given. The participants then brainstormed for 20 minutes. All ideas were written on a flip-chart. After 20 minutes of brainstorming, the participants were given the instruments to measure production blocking, social loafing, evaluation apprehension and ownership of the topic.

\subsection{Sample Size}

As six universities participated in this study, stratified random sampling was used to choose the subjects. Stratified random sampling is a good strategy to determine the subjects in the study. Stratified random sampling screens members of a population and reduces the variability of the sample size (Tuck man, 1994). This type of sampling facilitates a study of any differences that may exist within subgroups of the population. It also guaranteed that the various subgroups in the population are represented (Sekaran, 2(00). After this stratified random sampling technique was implemented, simple random sampling was applied. From an initial number of 579 undergraduates, the number was reduced to 460 Industrial Design students.

\subsection{Group-level Analysis}

In the group performance study, the suitability of operationalization depends on the nature of the task that will be completed by the group, the research question being asked, and the specific traits being analyzed. A task, according to Steiner (1972) is a 'job assignment' that would be achieved by the group. Steiner (1972) classified the task into four categories: The first category is a disjunctive task. It refers to a task that is determined by the best group members. The second category is a conjunctive task. It refers to a task that is determined by the worst group members. An additive task is the third category. It refers to a task that is determined by the sum of all members' contributions. The last category is a compensatory task. It refers to a task that is determined by the range and distribution of responses within the group (one man, one vote). Steiner (1972) also observes that "In real life, many tasks are additive." (pp.33). Therefore, in the case of brainstorming, Bolin and Neuman (2006) emphasized that group-level analysis is an 
appropriate method to be used. This is because, the idea contributed is not owned by the individual but the group. Therefore, analysis at group-level is appropriate.

\subsection{Instrument Measurement}

\subsubsection{Production Blocking}

The Process instrument(Bolin, 2002; Bolin\& Neuman, 2(06) was used to measure the process of Production Blocking, Social Loafing, and Evaluation Apprehension. In this study, an adapted version of Production blocking (Bolin, 2002; Bolin \& Neuman, 2(06) was used. This instrument was aimed at measuring Production blocking. Originally, this instrument consisted of 12 items (Bolin, 2(02). These items were measured based on a five-point Likert scale that ranges from "strongly agree" to "strongly disagree". Production blocking included items such as the following: "It was hard to know when it was my turn to talk", "It was hard to concentrate on my ideas while others in the group were talking" and the reverse item such as "I felt I could speak up whenever I had something to say". The internal consistency coefficient of five items was also high (Cronbach's alpha $=.84)$. This indicates that this instrument was suitable to measure production blocking in group brainstorming sessions.

\subsubsection{Social Loafing}

This instrument was aimed at measuring Social Loafing. Originally, this instrument contained 13 items (Bolin, 20(2). These items were measured based on a live-point Likert scale that ranged from "strongly agree" to "strongly disagree". Social loafing had an item such as "I didn't try very hard to help complete the group task" and "I really didn't take this task seriously". The reverse item such as "working in a group helps me feel motivated" and "I was very motivated to generate quality ideas" were provided. The internal consistency coefficient of six items was high (Cronbachs alpha $=.80$ ). This indicates that this instrument was very good and suitable to measure social loafing in group brainstorming sessions.

\subsubsection{Evaluation apprehension}

In this study, evaluation apprehension refers to a subject's responses to the instrument of evaluation apprehension (Bolin, 2002; Bolin \& Neuman, 2(06). These items were measured based on a live-point Likert scale that ranged from "strongly agree" to "strongly disagree". Sample items include "I felt apprehensive about sharing my ideas with the group" and "I didn't express all of my ideas because I didn't want the members of my group to think I was weird or crazy". The internal consistency coefficient of seven items was also high (Cronbach's alpha $=.77$ ). This indicates that this instrument was very good and suitable to measure evaluation apprehension in group brainstorming sessions.

\subsubsection{Ownership of the topic}

The Ownership of the Topic instrument developed by the researcher was used to measure the 
Ownership of the Topic. Originally, this instrument contained 15 items. These items were measured based on a five-point Likert scale ranging from "strongly agree" to "strongly disagree". Ownership of the Topic had items such as "The problem in the brainstorming should suit with my area", "I feel that the brainstorming problem was related with my field" and "If such problem is going to be held in the future, I will be willing to participate". The internal consistency coefficient of fourteen items was also high (Cronbach's alpha $=.93$ ).

\subsubsection{Quantity of ideas}

Quantity of ideas was based on the result of ideas produced during the brainstorming session. It was defined as non-redundant ideas. Once the number of quantity of ideas from Rater I was determined, the number of ideas from Rater 2 was also determined. The value was calculated by using the formula:

That is adapted from Dennis, Valacich, Connolly, \& Wynne (1996). The value of two raters' counts was .99. It shows that there was high interrater reliability and the quantity of ideas was satisfactory. Hence, the number of Rater 1 was used.

(Calculated as 1 - number of disagreement) Number of ideas

$$
12=0.99131384
$$

\subsection{Interrater reliability-group-level Analysis}

Before the data is computed to the group-level analysis, interrater reliability should be examined. It was determined by using the formula from James, Demaree, and Wolf (1984). The purpose of the interrater reliability was to examine the degree of differences of individual scores in the group (James et al., 1984). The formula is shown below:

$$
\begin{aligned}
r W G(J) & =\frac{J\left[1-\left(S x j^{2} / \sigma E U^{2}\right)\right]}{J\left[1-\left(\mathrm{Sxj}^{2} / \sigma E U^{2}\right)\right]+\left(\mathrm{Sxj}^{2} / \sigma E U^{2}\right)} \\
& -\frac{J\left[1-\mathrm{Sxj} \mathrm{j}^{2} /\left(\mathrm{A}^{2}-1 \gamma 12\right)\right]}{J\left[1-\mathrm{Sxj} /\left(\mathrm{A}^{2}-1 \mathrm{~W} / 12\right)\right]+\mathrm{Sxj}^{2} /\left(\mathrm{A}^{2}-1\right) / 12}
\end{aligned}
$$

$J=$ the number of item

$\mathrm{Sxj} \mathrm{j}^{2}=$ variance

$\left.\sigma E U^{2}=\left(A^{2}-1\right) / 12\right)$

$A^{2}=$ scale (e.g. 1-5, 1-7)

Mean interater reliability were Production Blocking $\left(R_{\text {way }}=.70\right)$, Social Loafing $\left(\mathrm{R}_{\text {way }}=93\right)$, Evaluation Apprehension $\left(\mathrm{R}_{\text {woil }}=.80\right)$, and Ownership of the Topic $\left(R_{\text {wral }}=.89\right.$ ). These results justified that the data be aggregated to the group-level. 


\subsection{Data Analysis}

Table I shows the relationship between Production blocking and the quantity of ideas shared among industrial design students is significant $(r=-.38, P<.01)$. The relationship between Social loafing and the quantity of ideas shared among industrial design students is significant $(r=-.21$ $, P<.05)$. The relationship between Evaluation apprehension and the quantity of ideas among industrial design students is also significant $(r=-.22, p \ll .05)$. The positive association between Ownership of the topic and quantity of ideas is also significant $(r=.26, P<.01)$.

Table 1: Correlation analysis $(\mathrm{N}=115)$

\begin{tabular}{lcccc}
\hline Variables & $(1)$ & $(2)$ & $(3)$ & $(4)$ \\
\hline 1. Production blocking & 1.00 & $\cdots$ & $\cdots$ & $\cdots$ \\
2. Social toating & $.753^{* *}$ & 1.00 & $\ldots$ & $\cdots$ \\
3. Evaluation apprehension & $.710^{* *}$ & $.785^{* *}$ & 1.00 & - \\
4. Ownership of the topic & $-471^{* *}$ & $-579^{* *}$ & $-.626^{* *}$ & 1.00 \\
5. Quantity of ideas & $-367^{* *}$ & $-205^{*}$ & $-.219^{*}$ & $258^{* *}$ \\
\hline
\end{tabular}

Note: "* Correlation is significant at the 0.01 level (2-taned); " Correlation is significant at the 0.05 level (2-tailed), $t$ Correlation is significant at the 0.10 level (2-tailed).

\subsection{Hypothesis Testing}

Data in this study is analyzed by using Partial Least Squares (PLS). PLS is a second generation multivariate technique in data analysis (Haenlein \& Kaplan, 20(4). PLS has the advantage to handle some problems such as:

1. multicollinearity among independent variable

2. data that is not normally distributed

3. scales which could be nominal, ordinal, interval or ratio (scale-robust)

4. models with either reflective, formative, or both, reflective and formative

5. small sample size

6. missing value

\subsubsection{Assessment of the Model}

Using Structural Equation Modeling (SEM) with Partial Least Squares (PLS) requires the researcher to perform two major steps: (1) assessing the measurement model in order to examine both convergent and discriminant validity and (2) assessing the structural model in order to examine the path coefficient (Hulland, 1999).

Convergent and Discriminant Validity

In PLS, firstly, the loading in the same block should be higher than the other blocks. This means that there is high convergent validity. A standardized loading that is recommended in the measurement model is .70 (Chin, 1998). 
Nevertheless, loading of .50 and .60 are also still acceptable when the construct is the new construct and the model is still new (Imam Ghozali, 2(06). In this study, the researcher applied the loading $01^{\prime} 0.60$ since the model using PLS is still new in group performance research. Table 2 shows the loadings within the same construct and the other constructs.

Discriminate validity in PLS is assessed by three criteria:(I)factor loadings for all items should be .60 and above (2) composite reliability should be .70 and above and(3) AVE must show the cut-off .50 which indicating at least $50 \%$ of the measurement variance (Fornell \& Larcker, 1(81).

Table 2: Cross loadings Between Constructs

Note: $\mathrm{pb}=$ production blocking, $\mathrm{sl}=$ social loafing, ,evaluation apprehension, top= owners hip of the topic.

\begin{tabular}{|c|c|c|c|c|c|}
\hline & $\begin{array}{l}\text { PRODUCTION } \\
\text { BLOCKING }\end{array}$ & $\begin{array}{c}\text { SOCIAL } \\
\text { LOAFING }\end{array}$ & $\begin{array}{l}\text { EVALUATION } \\
\text { APPRENSION }\end{array}$ & \begin{tabular}{|c|} 
OWNERSHIP \\
OF THE TOPIC \\
\end{tabular} & $\begin{array}{l}\text { QUANTITY } \\
\text { OF IDEAS }\end{array}$ \\
\hline pb1 & 0.866 & 0.662 & 0.584 & -0.357 & -0.377 \\
\hline pb11 & 0.769 & 0.762 & 0.754 & -0.403 & -0.219 \\
\hline pb2 & 0.872 & 0.643 & 0.643 & -0.408 & -0.381 \\
\hline pb4 & 0.847 & 0.764 & 0.679 & -0.389 & -0.235 \\
\hline pb6 & 0.831 & 0.657 & 0.599 & -0.364 & -0.342 \\
\hline sl 1 & 0.611 & 0.775 & 0.684 & -0.367 & -0.181 \\
\hline sl 4 & 0.764 & 0.908 & 0.732 & -0.476 & -0.268 \\
\hline sl 5 & 0.744 & 0.927 & 0.707 & -0.484 & -0.345 \\
\hline ea 5 & 0.730 & 0.788 & 0.953 & -0.499 & -0.234 \\
\hline ea 7 & 0.714 & 0.736 & 0.949 & -0.525 & -0.225 \\
\hline top 1 & -0.316 & -0.374 & -0.346 & 0.727 & 0.101 \\
\hline top 11 & -0.343 & -0.411 & -0.381 & 0.826 & 0.273 \\
\hline top 12 & -0.409 & -0.446 & -0.450 & 0.782 & 0.297 \\
\hline top 14 & -0.415 & -0.450 & -0.418 & 0.739 & 0.276 \\
\hline top 15 & -0.457 & -0.453 & -0.641 & 0.665 & 0.093 \\
\hline top 2 & -0.322 & -0.403 & -0.412 & 0.782 & 0.139 \\
\hline top 3 & -0.196 & -0.268 & -0.291 & 0.758 & 0.259 \\
\hline top 4 & -0.345 & -0.377 & -0.419 & 0.838 & 0.278 \\
\hline top 5 & -0.465 & -0.490 & -0.540 & 0.759 & 0.247 \\
\hline top 6 & -0.356 & -0.439 & -0.500 & 0.774 & 0.130 \\
\hline top 7 & -0.326 & -0.406 & -0.446 & 0.865 & 0.252 \\
\hline top 8 & -0.416 & -0.476 & -0.498 & 0.802 & 0.184 \\
\hline top 9 & -0.282 & -0.275 & -0.288 & 0.742 & 0.256 \\
\hline QUANTITY & -0.387 & -0.318 & -0.241 & 0.304 & 1.000 \\
\hline
\end{tabular}


Table 3 shows the composite for constructs greater than .70. Forncll and Larcker(1981) argued that composite reliability is more powerful than Cronbac h's alpha because it is determined by the relative loadings or the items and is not influenced by the number or items. Fornell and Larcker (1981) suggested the composite reliability cut-orr value .70 to be satisfactory for the constructs. The table also shows the value or Cronbach's alpha for all constructs. The results indicate that all constructs have satisfactory measurements (quantity or ideas has Composite reliability and Cronbac h's alpha value or I. This should not be interpreted as perfect indicators because it has absolute performance and is not measured by the number or items).

Table 3: Composite reliability and Cronbach 's alpha

\begin{tabular}{|c|c|}
\hline & Composite Reliability \\
\hline $\begin{array}{c}\text { PRODUCTION } \\
\text { BLOCKING }\end{array}$ & 0.922 \\
\hline SOCIAL LOAFING & 0.905 \\
\hline $\begin{array}{c}\text { EVALUATION } \\
\text { APPRENSION }\end{array}$ & 0.950 \\
\hline $\begin{array}{c}\text { OWNERSHIP OF THE } \\
\text { TOPIC }\end{array}$ & 0.951 \\
\hline QUANTITY OF IDEAS & 1.000 \\
\hline
\end{tabular}

\begin{tabular}{|l|c|}
\hline & Cronbachs Alpha \\
\hline $\begin{array}{l}\text { PRODUCTION } \\
\text { BLOCKING }\end{array}$ & 0.895 \\
\hline SOCIA t.: LOAFING & 0.847 \\
\hline $\begin{array}{l}\text { EVALUATION } \\
\text { APPRENSION }\end{array}$ & 0.895 \\
\hline $\begin{array}{l}\text { OWNERSHIP OF THE } \\
\text { TOPIC }\end{array}$ & 0.945 \\
\hline QUANTITY OF IDEAS & 1.000 \\
\hline
\end{tabular}

In the case or discriminate validity, Table 2 also reflects the loadings or items on their own constructs. It shows that the loadings or all constructs within the same construct are expected to be high on this construct, indicating high convergent validity. Meanwhile, low on the other constructs indicates high discriminate validity. Table 2 shows a clear convergent and discriminate validity for all constructs. The items in all the respective constructs show higher loadings than other constructs.

Table 4 shows that AVE for Production blocking is .70, Social loafing is .76, Evaluation apprehension is .91, and ownership of the topic is .60. All the constructs have a value above .50 . 
Table 4: Average Variance Extracted (AVE)

\begin{tabular}{|c|c|}
\hline \multicolumn{2}{|c|}{ AVE } \\
\hline $\begin{array}{c}\text { PRODUCTION } \\
\text { BLOCKING }\end{array}$ & 0.702 \\
\hline SOCIAL LOAFING & 0.761 \\
\hline $\begin{array}{c}\text { EVALUATION } \\
\text { APPRENSION }\end{array}$ & 0.905 \\
\hline $\begin{array}{c}\text { OWNERSHIP OF } \\
\text { THE TOPIC }\end{array}$ & 0.601 \\
\hline $\begin{array}{c}\text { QUANTITY OF } \\
\text { IDEAS }\end{array}$ & 1.000 \\
\hline
\end{tabular}

\subsection{Assessing the Structural Model}

In order to estimate the statistical significance of the parameter estimates, a bootstrapping procedure with replacement using 500 subsamples was used in this study. Bootstrapping was used for the purpose of eliminating the assumption of normality. Since all hypotheses are not directional, this study used a two-tailed t-test. This means that a $90 \%$ level of confidence or $p<.10$ level of significance needs t-value $>1.645,95 \%$ level of confidence or $p<.05$ level of significant needs t-value $>1.960$, and $99 \%$ level of confidence or $p<.0$ l level of significant needs t-value $>2.576$.

\subsubsection{Direct Effects of Processand Ownership of theTopicon Group Brainstorming Performance}

This study hypothesized that Production loss is related to the quantity of ideas shared by Industrial design students. Table 5 shows the direct effects of production loss on the quantity of ideas. The results revealed that production blocking had negative effects on the quantity of ideas $(\sim=-.43, p<.0 \mathrm{I})$., therefore supporting H1a.However, the results also showed that Social loafing ( $=-.05, p>.10$ )was not significant. Hence, $\mathrm{H} 2 \mathrm{~b}$ was not supported. Evaluation apprehension had significant effects on the quantity of ideas $(\sim=.24, p<.10)$, indicated that $\mathrm{H} 1 \mathrm{c}$ was supported.

This study also hypothesized that Ownership of the topic is related to quantity of ideas amongIndustrialdesignstudents. Table5showsthatthedirecteffect of Ownership of the topic is related to the quantity of ideas shared by Industrial design students. Result showed that Ownership of the topic had significant effects on the quantity of ideas $«(3=.21, p<.(5)$, therefore supporting $\mathrm{H} 2$.

Overall, as shown in Figure 2, this research model explained 19 percent of the variance in group brainstorming performance $(\mathrm{R} 2=.19)$. This indicates that Production loss of production blocking and evaluation apprehension are powerful predictors of group brainstorming performance. Ownership of the topic also contributes to group brainstorming performance 
Zainol, A.S., et.al., / Asian Journal of Environment-Behaviour Studies, ajE-Bs, 1(1), Maiden, December 2016 (p.19-35)

Table 5: Direct Effects of Process and Ownership of the topic on Group Brainstorming Performance

\begin{tabular}{|l|c|c|c|}
\hline & B & T-statistics & $\begin{array}{c}\text { Hypothesis } \\
\text { Supported }\end{array}$ \\
\hline production blocking -c-quantity of ideas & -0.434 & 3.250 & Yes \\
\hline Social loafing -> quantity of ideas & -0.051 & 0.405 & No \\
\hline $\begin{array}{l}\text { Evaluat ion apprehension -> quantity of } \\
\text { ideas }\end{array}$ & 0.243 & 1.683 & Yes \\
\hline Ownership of the topic -> quantity of ideas & 0.212 & 2.329 & Yes \\
\hline
\end{tabular}

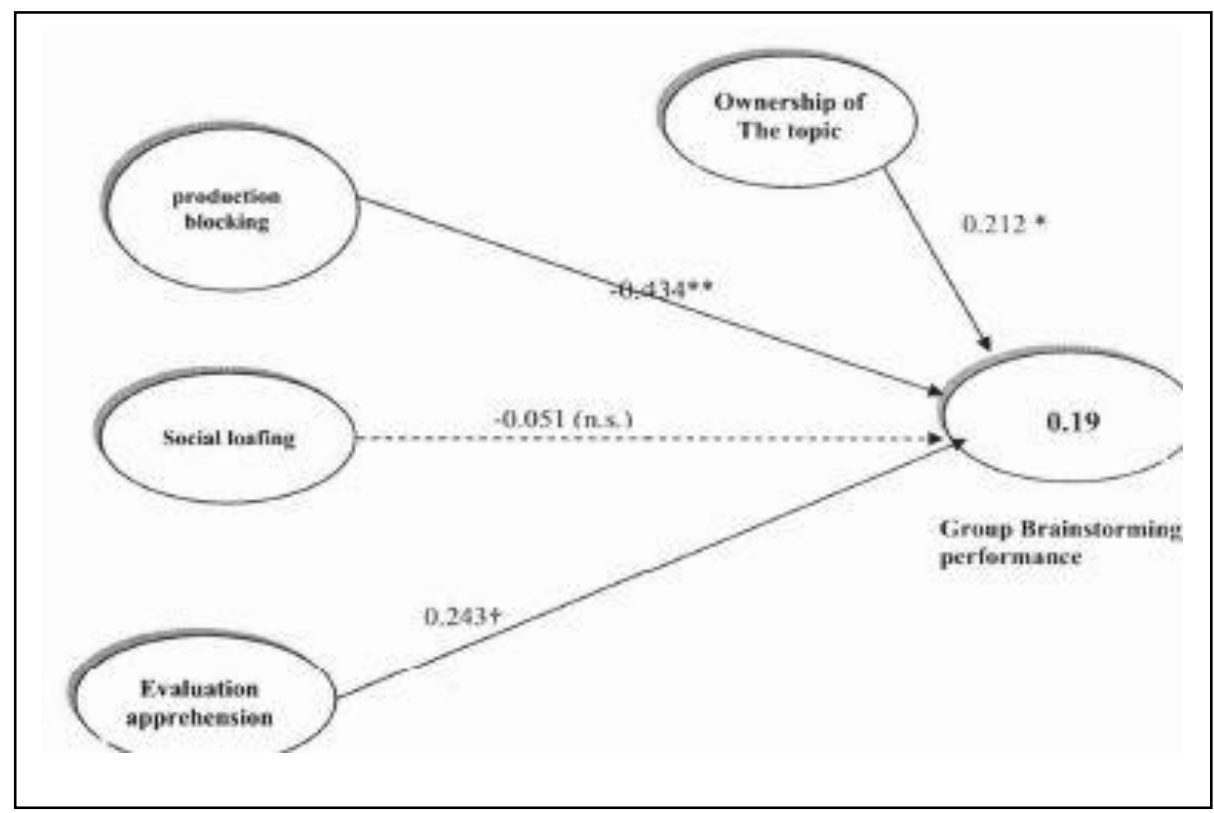

Figure 2: Model of Process in Group Brainstorming

\subsection{Discussions and Conclusions}

The results of this study support the hypotheses that production loss as a unique predictor of group brainstorming performance. For each specific process, production blocking and evaluation apprehension are the strongest predictors whereas social loafing is not a predictor to group brainstorming performance. These findings are congruent with past research on brainstorming (Diehl \& Stroebe, 1987; Diehl \& Stroebe, 1991).

For evaluation apprehension, the positive relationship with group brainstorming performance 
is not in line with the previous researches such as those by Barki and Pinsonneault (20()J) and Mullen et al. (1991). The results of this study on the production loss suggest that a group that has high production blocking would produce less idea compared to a group of industrial design students that has evaluation apprehension. The findings also revealed that ownership of the topic is a good predictor to the group brainstorming performance. This result is consistent with the finding by Barki and Pinsonneault (2001) and Nijstad et al. (2006). The results also suggest that in order to enhance the group brainstorming performance, the topic which is parallel with the participants' interests should be considered as mentioned by Zainol and Yusof (2008). The positive relationship between ownership of the topic and quantity of ideas for the current sample is similar to the findings from previous research that had established that the topic the participant owns would produce better performance (Paulus \& Brown, 2(03).

This study offers some theoretical and practical implication. Firstly, the topic that was given in the brainstorming session should be explored in future studies because it may influence the results in other brainstorming research. Secondly, the topic given should come from experts in the area of study. Surprisingly, even though almost all studies agree that evaluation apprehension results in prominent loss, this study found that it acts positively in group brainstorming performance within the industrial design context. It appeared in this study that the participants in the group brainstorming sessions contributed more ideas when they felt they were being evaluated by the other members.

This study also has a few limitations. Firstly, this study is limited to undergraduates who were pursuing Industrial Design courses in six public university in Malaysia. Any attempt to generalize this study to any other area and even private colleges must be proceeded with caution. Second, even though most of the hypotheses are supported, 19 percent of the variance explained in this study should be taken into account by future researchers.

\section{Acknowledgement}

We would like to thank Universiti Teknologi Mara (UiTM) for giving us the research grant. We also thank the participants from the International Islamic University, Malaysia (HUM), Universiti Teknologi Malaysia (UTM), Universiti Sains Malaysia (USM), Universiti Malaysia Sarawak (UNIMAS), Universiti Teknologi MARA (UiTM), and Universiti Putra Malaysia (UPM) for participating in this study

\section{References}

Barki, H. \& Pinsonneault, A. (2001). Small group brainstorming and idea quality: Is Electronic brainstorming the most effective approach. Small group Research. 32. 158-205.

Bolin, A.U., (2002). The Relationships among Personality. Process, and Performance in Interactive Brainstorming Groups. Unpublished Dissertation. Northern Illinois University. 
Bolin, A.U. \& Neuman, G.A. (2006). The relationships among personality, process, and performance in interactive brainstorming groups. Journal of Business and Psychology. 20. 565-585.

Bouchard, TJ. and Hare, M. (1970). Size, performance, and potential in brainstorming Groups. Journal ofApplied Psychology. 54. 51-55.

Chin, W.W. (1998). The partial least squares approach for structural equation modeling. In G.A. Marcoulides (Ed.), Modern Methods FJr Business Research, 295-336, Mahwah, NJ: Lawrence Erlbaum.

Cohen, J., Cohen, P., West, S.G., \& Aiken, L.S. (2003). Applied multiple correlation! regression analysis for the behavioral sciences. Mahwah, NJ: Lawrence Erlbaum Associates.

Coskun, H. (2005). The effects of social identity and role taking on productivity in Individual brainstorming. Turk Psikoloji Dergisi. 20, 133-136.

Dennis, A.R., \& Valacich, 1.S.(1993). Computer Brainstorms: More Head arc Better Than One. Journal ofApplied Psychology, 78, 531-537.

Dennis, A.R. \& William, M.L. (2003). Electronic brainstorming: Theory, research, and Future direction. in Paulus, P.B. and Nijstad, B.A. (cds.). Group creativity: Innovation Through collaboration. 160-178. New York: Oxford University Press.

Diehl, M., \& Stroebe, W. (1987). Productivity loss in brainstorming groups: Toward The solution of a riddle. Journal ofpersonality and social psychology. 53, $497-509$.

Dorval, K.B. (1999). Strengthening the 'Heartbeat' of creative problem solving-Strategies for facilitating small groups. Prepaid for $6^{\text {th }}$ European Conference on Creativity and Innovation. Dec. 12-15, 1999, Lattrop, the Netherlands.

Ekberg, K. (2005). Design Investment in Small Wood Manufacturing Companies-Problems and Possibilities of Using Design Expertise in Product Development. Unpublished Dissertation. Lulea University of Technology.

Funk, R.L. (2000). Let's think like an industrial designer. Technology and Children, 5, 3-5.

Furnharn, A. \& Yazdanpanahi, T.( 1995). Personality Differences and groups versus Individual brainstorming. Personality individual differences. 19, 73-80.

Gallupc, R.B., Dennis, A.R., Cooper, W.H., Valacich, J.S., Bastianutti, L.M. \& Nunamaker Jr., J.F. (1992). Group size \& electronic brainstorming. AcademyOf Management Journal, 35, 350-369.

Hacnlcin, M. \& Kaplan, A.M. (2004). A beginner's guide to partial cast squares analysis. Understanding Statistics, 3 , 283-297.

Hannah, B. (2004). Becoming a Product Designer. New Jersey.John Wiley \& Sons, Inc.

Hulland, J. (1999). Use of Partial Least Squares (PLS) in strategic management research: A review of four recent studies. Strategic Management Journal, 20, 195-204.

Imam Ghozali (2006). Structural Equation Modeling, Metode Alternati] dengan Partial Least Square (PLS). Semarang: Badan Penerbit Universitas Diponegoro. 
Industrial Design Society of America IDSA. (2004). IDSA About ID Section. http://www. idsa.org/absolutenm/templates/?a=1|9\&z=23 Retrieved 14 December 2008

Isaksen, S.G. (1998). A review of brainstorming research: Six critical issues [or enquiry (Monograpli \#3(2). Buffalo, NY: Creative Problem Solving Group-Buffalo.

James, L.R., Demaree, R.G., \& Wolf, G. (1984). Estimating within-group interrater reliability with and without response bias. Journal ofApplied Psychology, 69, 85

98.

Karau, S.J. \& Williams, K.D. (1993). Social Loafing: A Meta-Analytic Review and Theoretical Integration. Journal of Personality and Social Psychology, 65, 681

706.

Kcinoncn, T. (2006). The concept design team. In Takala, R. \& Keinonen, T. (cds.). Product Concept Design: Review of Conceptual Design (if Production in Industry, 34-56.

Germany:Springer. Kelly, T. (200 I). The Art (if Innovation: Lessons in Creativity from IDEO, America's Leading Design Firm. New York: Doubleday.

Latane, B., William, K., \& Harkins, S.G. (1979). Many hands make light the work: the Causes and consequences of social loafing. Journal of Personality and Social Psychology, 37, 1122-832.

Mullen, B., Johnson, C.; \& Salas, E. (1991). Productivity loss in brainstorming groups: a meta-analytic integration. Basic and Applied Social Psychology, 12,3-23.

Naveiro, R.M. \& Pereira, R.c. (2008). Design education in Brazil, Design Education, 29, 304-312.

Nickerson, R.S. (2003). Enhancing creativity. In Sternberg, R.J.(Eds.). Handbook ( I Creativity. 392-430. Cambridge: University Press.

Nijstad, B.A., van Vianen, E.M., Stroebc, W., \& Lodcwijkx, H.F.M. (2004). Persistence in Brainstorming. Exploring Stop Rules in same-Sex Group. Group Process \& Intergroup Relations, 7, 195-206.

Nijstad, B.A., Stroebe, W., \& Lodewijkx,H.F.M. (2006). The Illusion of Group Productivity : A Reduction of Failures Explanation.. European Journal of Social Psychology, 35, 31-48.

Osborn A.F. (1963). Applied Imagination: Principles and Procedures of creative Problem solving. (2nd.). New York: Scribner's.

Paulus, P.B. \& Brown, V.R. (2007). Toward more creative and innovative group idea Generation: A cognitive social-motivational perspective of brainstorming. Social and Personality Psychology Compass, I, 248-265.

Paulus, Paulus, P.B. \& Nijstad, B.A. (2003).Group creativity: Innovation through Collaboration. In Paulus, P.B. and Nijstad, B.A. (eds.), Group creativity: Innovation Through collaboration. 32-62. New York: Oxford University Press.

P.B., Dzindolet, M.T., Polctcs, G., \& Camacho, L.M. (1993). Perception of Performance in Group Brainstorming: The Illusion of Group Productivity. The Society For Personality and Social Psychology. 19, 78-89.

Paulus, P.B., Larcy, T.S., Putman, V.L., Leggett, K.L., \& Roland,EJ. (1996). Social Influence processes in computer 
brainstorming. Basic and Applied Social Psychology, 18, 3.

Rahman, K.A.A. (2005). Knowledge Conversion in design Management Practices: An attitude study of designers in Malaysian industrial clusters. Paper Presented at Internationalizing Applied and Creative Arts of South East Asia, Kuching, Sarawak, Malaysia. 5-6 December 2005.

Rawlinson, J.G. (1981). Creative Thinking and Brainstorming. Hants, England: Gower Pub. Co. Ltd.

Roozcnbcrg, N \& Eekels, J. (1995). Product Design: Fundamentals and Methods. UK: John Wiley and Sons Ltd.

Sekaran, U. (2000). Research method for business: A skill-building approach. New York: John Wiley \& Sons, Inc.

Shepherd, M.M., Briggs, R.O., Reinig, B.A., Yen, J., \& Nunamaker Jr., J.F. (1996). Invoking social comparison to improve electronic brainstorming: Beyond anonymity. Journal of Management Information System. 12, 155-170.

Stroebe, W., Diehl, M., \& Abakoumkin, G. (1992). The illusion of group effectivity. Personality and Social Psychology Bulletin, 18,643-650.

Taylor, D.W., Berry, R.C., \& Block, C.N. (1958). Does group participation when using Brainstorming facilitate or inhibit creative thinking? Administrative Science Quarterly, 3, 23-47.

Tuckman, B.W. (1994). Conducting Educational Research ( $4^{\text {th }}$ Ed). New York: Harcourt Brace College Pub.

Zainol, A.S. \& Yusof, W.Z.M. (2008). The relationships between personality of product designers process toward group brainstorming. Paper Presented at 2nd-International Conference on Applied and Creative Arts, Kuching, Sarawak, Malaysia. 16-17 January 2008. 